\title{
Social Memory: From Oblivion or Construction to Cultural Trauma
}

\author{
Bayan Zh. Smagambet ${ }^{1}$, Almash A. Tlespayeva ${ }^{1}$ \& Ainur B. Musabayeva ${ }^{1}$ \\ ${ }^{1}$ Department of Sociology, L.N. Gumilyov Eurasian National University, Nur-Sultan, \\ Republic of Kazakhstan. ORCID: oooo-ooo1-7194-3952. \\ Email: tlespayeva5271@murdoch.in
}

\begin{abstract}
The formation of social memory is an important component of the state humanitarian strategy. It acquires special significance in the conditions of postmodern transformations of a transitional society, which directly relate to the functioning of the political system. Thus, the process of democratic transition is becoming an undeniable and peremptory reality. The necessity for liberal political and economic reforms is also not much controversial. With this state of affairs, ideological discussions acquire a retrospective direction, their subject is not the search for development models for the future, but the construction of models for assessing the past. The novelty of the study is determined by the need to assess social participation on the part of both individual and public entities. The authors classify not only the population as social entities but also the carriers of the cultural code, who may belong to extraterritorial groups. The article shows that social memory can also be considered as a method of socio-economic development of a territory, and in order to achieve political objectives by individual groups of capital. The practical significance of the study is determined by the possibility of structuring social memory and building on this basis socio-economic strategies for the development of a sustainable society.
\end{abstract}

Keywords: structure, development, society, political influence, communication.

\section{Introduction}

Before defining the conceptual characteristics of memory politics, it is necessary to determine the place of social memory in the course of the implementation of actions of political influence. The structural elements of political influence are: the subject (agent, initiator of interaction), the object of impact and the environment in which the interaction takes place. Each of these components has its own characteristics, which determine the peculiarities of the implementation of influence in a particular case. The initiator of influence has a goal for the sake of which the action takes place, and the means of influence that characterise his ability to achieve the goal. It is the goal that determines the choice of means of influence. The latter should be divided into two interrelated groups: resources of influence and instruments of influence (Maswood \& Rajaram, 2019; Skrypnikova, 2020). The object of political influence constitutes a certain sphere/attribute of the addressee of influence, on the change of which the influence is oriented. It can be: will, emotions, consciousness, individual action or behaviour in general, beliefs, identity, and the like. The intrinsic characteristics of the object of impact are also decisive, which determine the ability to accept or resist influence (Olick \& Robbins, 1998). These include the level, suggestibility, personal attitude to

(C) AesthetixMS 2021. This Open Access article is published under a Creative Commons Attribution Non-Commercial 4.0 International License (http://creativecommons.org/licenses/by-nc/4.o/), which permits non-commercial re-use, distribution, and reproduction in any medium, provided the original work is properly cited. For citation use the DOI. For commercial re-use, please contact editor@rupkatha.com. 
the opposite side in interaction, peculiarities of treatment in a team, a tendency to succumb to or to resist group pressure, crowd effects. These components and their interaction are mediated by the characteristics of the environment in which the impact occurs. These include: the type of political system, the well-functioning of communication ties, the nature of political culture, social traditions and group norms.

Social memory is an important factor in exercising political influence (Carleton et al., 2013). As an element of political influence, social memory can determine each of its characteristics: resources, means, object, subject, level of influence, and the result obtained (Wilson, 2015; Kukharchuk, 2018). When a certain type of social memory is formed, it is actually an object of political influence (Bekus, 2019). In accordance with constructivist theories, social memory is formed depending on current social and political interests (Mistry et al., 2014). Accordingly, actualised images are introduced or stimulated externally, and are not directly adopted experiences (Wilson et al., 2017). Therefore, the consolidation or reconstruction of a certain image, state, assessment or model of social memory can be the goal of the influence of the subjects of the political process (Lalioti, 2002).

Social memory as a resource for political influence acquires potential in the information age, when information becomes the leading measure of power and influence (Overholtzer \& Bolnick, 2017). At the same time, the postmodern discourse has shifted public emphases from basic narratives and social modernisation projects to programs of reconstruction and retransmission of the past (Williams, 2011). Therefore, according to the typology of resources of influence, the content of social memory can be attributed to cultural and information resources of influence (Delyser, 2015). In particular, social memory is a source of argumentation in political discussions, for example, to legitimise a country's gaining independence or being in power (Tileagă, 2012). Memory as a resource of influence helps to confirm/justify the correctness and legitimacy of political decisions or actions (Henninger \& Scifleet, 2016).

The mobilisation potential of memory is often used as an instrument of influence in the political sphere (Foster et al., 2011). In this case, the structures of consciousness are involved not just to confirm the subject's arguments, but to change the structures of the inner world, consciousness, value orientations and norms of behaviour of the addressee of the impact, which corresponds to the normative impact (Gainullina et al., 2014; Tovkanets, 2020). Social memory as a contextual factor (environmental factor) of political influence preserves the norms and patterns of behaviour inherent in the respective culture, characteristics of the psychological make-up of the community (Sebald \& Weyand, 2011). Memory determines acceptable and unacceptable patterns of interaction between subjects and objects of politics and does not depend on their will (Romano et al., 2020).

Almost all concepts of "sociality" contain a component of social memory immanently. Memory appears in its transformed forms, reflects the experience of social interaction, social relations, norms of use, and so on. According to the dictionary definition, "Social memory is the memory that manifests itself in communication with other people: on faces, names of interlocutors, their voices, events in their lives." In the process of forming a norm, there is such a kind of social memory as a fixed successful experience of use corresponding to a relationship partner. Social memory allows avoiding construction of a long series of tests according to the "trial-error" model, since it fixes the previously found method and form of interaction, social connection in the standard of behaviour in typical situations, norm, moral dogma. Social memory underlies the formation of speech and, more broadly, symbolic interactions. Having accidentally arisen, a certain phenomenon 
is embraced by consciousness and fixed as an experience. All practical, purposeful activities are anchored in the social memory of successful experiences (Bocharova, 2018; Poghosyan, 2018).

Just as the hand remembers a successful and effective movement in sports, labour and then reproduces this movement and repeats it many times, so a randomly found way of relationship is fixed in social memory and is repeated many times in typical situations, which allows consistently achieving success in a relationship with close interactions. Physiological memory of a trained movement simulates the phenomenon of social memory in the functioning of a social institution. Forms of social memory are classified according to the nature of social phenomena enshrined in norms; patterns stored for further repeated repetition. All this has determined the relevance of the problems that are considered.

\section{Materials and methods}

The question arises about the ethics of manipulating public memory. At all times, the government has been a monopoly on the writing of history, because this phenomenon has existed for a long time and to one degree or another is inevitable (Hewer \& Roberts, 2012). The moral and ethical limits of the use of social memory in politics are determined not by those who use it, but by the extent to which the retranslated memory content corresponds to objective realities (Swann \& Miller, 1982). In fact, the limits of admissibility of such influence are determined by the goal set by the agent of influence: socially significant and committed to other communities, or individuallycorporate, accompanied by aggression towards opponents (Olick, 2009). Acceptable:

1. Object: consolidation of a single model of national memory, the formation of national consciousness and social identity, the inclusion of values in the national mentality.

2. Resource: a legitimation of the state's independence as the nation's self-determination, proof of the people's belonging to world civilization.

3. Tool: mobilisation of civil society to control power and solve internal problems, the growth of patriotic feelings, military mobilisation to resist possible aggression.

Unacceptable:

1. Object: winning the elections, discrediting a political opponent and his electorate, hindering the growth of public activity.

2. Resource: justification of repressions against the population, a legitimation of military aggression, evidence of the legitimacy of the authorities' criminal actions.

3. Instrument: strengthening of depressive moods, the formation of traumatic states of public consciousness, disintegration or split of society, and the like.

As an element of the functioning of a political system, social memory can act in the opposite hypostases: the object of politics and/or its means. In the case when memory is the object of purposeful activity of state authorities, one should speak of the "memory politics".

\section{Results and discussion}

There are different terms for the relevant public policy. The following definitions are presented. Memorial policy is a component of systematic and consistent state policy in the field of forming social and national memory. Memory politics is a real space for the creation of new political relations based on the interpretation and representation of the public in the past; complex interaction of a number of subjects, aimed at supporting or revising individual elements of social memory; a set of actions designed to coordinate and mutually accept various interests in the 
interpretation of the past. The state memory politics is an important component of the political activity (humanitarian policy) of the state; a set of principles, methods and specific state and sociopolitical measures normalised in conceptual and legal relations with the use (accounting) of information about the social past in the processes of state (national-state) construction and sociocultural reproduction of a political nation. When considering this phenomenon, the historian points to the role of the political segment in the process of developing and shaping the values of the social past with a specific socio-political goal. Also, they emphasise the importance of the scientific basis in the development of the program of this policy. The content of the state memory politics is determined as purposeful, normalised from a constitutional and legal point of view, scientifically grounded efforts of the state aimed at identifying, preserving, affirming in the public consciousness the memory of the most significant events and processes of the past for the reproduction and life of a political nation in the interests of a sovereign state and civilisational progress.

Taking into account the above definitions, the authors consider it necessary to reveal the essence of this phenomenon in this way. Memory politics is the purposeful activity of government bodies, parties, public organisations to manage public memory by constructing/consolidating, deconstructing/eliminating or updating/returning an integral memory model or its individual components in order to form/correct the states of public consciousness and identity; a set of mechanisms, procedures and forms of interaction between the subjects of the political process, aimed at managing collective memory. It is worth noting that other synonymous terms are also used in scientific discourse: "memorial policy", "social policy". Less common are: "politics of the past", "mnemo-history", "politics of history", "chronopolitics", "politics of social time", "identity politics", "politics of national heritage", "symbolic politics". The task is not to oppose or compare different types of political practices, the reflection of the past, but to define their role in the social process. Therefore, in order to avoid frequent tautologies in the text, these terms are used interchangeably, unless otherwise indicated.

The use of this or that term in different countries is imprinted by scientific linguistic traditions, interstate contacts and the peculiarities of using the corresponding terminology. For example, English-language literature predominantly operates with the concept of "memory politics". Germany uses the category "Sozialpolitik" (social policy). In Poland, the term "polityka społeczna" (social policy) is widespread, where it is borrowed from the German language. It is characteristic that the term "social policy" (as opposed to "memory politics") has also found widespread use in the countries of the former USSR. Several reasons for the spread of this term in scientific and journalistic discourses can be identified: first, "social policy" is a copy of the German "Sozialpolitik"; secondly, the term was borrowed from the period of perestroika in the USSR, when a social policy was launched, which was aimed at eliminating the "white spots of history," that is, it concerned social science, not memory; thirdly, the term is deliberately used to oppose the "memory politics" as a way of "manipulating the past." Thus, there is a shift in emphasis - an illusion is created that the authorities do not manipulate history, but contribute to its "correct" coverage, "counteracts falsifications". Therefore, accordingly - on the initiative of the top state leadership with reference to the images of social memory, the following images are automatically legitimised by society, which:

- are based on scientifically reliable information;

- counteract the distortion of the perception of the past;

- restore social justice;

- contribute to ensuring state interests 
Scientific discourse is ambiguous about the correlation of these categories. Historians tend to distinguish between "social politics" (the activities of state elites aimed at rewriting history and deformation of public memory, targeted political influence on social science) and "memory politics" (understanding the conditions for the coexistence of various layers of social memory and corresponding experiences). At the theoretical level, the authors consider it inappropriate to make such a rigid opposition of these terms' absolute. First: in the above distinction, the content of the respective practices is replaced by the motives of their performers. Secondly: comprehension of social memory and its formation/deformation (including with the help of social education) are inseparable components in the implementation of the civilised process of managing collective memory. They offer such an option for correlating these categories: there is every reason to apply the concept of "memory politics" as a generalisation, "social policy" - as clarifying to denote its state and legal aspects, and the rarely used concept "mnemonics in history" - as a use social heritage in the very process of remembering.

The authors believe it expedient to consider social and memorial policies as separate components of memory politics. It is advisable to characterise their content based on the semantics of terms. In particular, the memorial policy should be outlined as including procedures for the formation of places of memory and commemorative practices of honouring the past. At the same time, social policy is focused on the formation and representation of the basic narrative in school education, media discourse, cinema, and the like. In terms of the scale of implementation, memory politics, like any other, can have a global, continental, state, regional, local, corporate level. The study deals specifically with public policy, unless otherwise indicated.

For a better disclosure of the content of the implementation of memory politics, the authors use the category "memorial actions" as a direct specific public expression of memory politics. Memorial action (from Lat. Memoria - "memory" and actio - "to act") is a social and political action of a public nature, associated with the formation of collective memory. Examples of commemorative actions are: opening a monument, issuing a commemorative coin, naming a famous figure in a particular institution, celebrating the anniversary of a social event. Committing acts of vandalism against monuments are also, to a certain extent, commemorative actions, but aimed not at supporting/honouring, but condemning/discrediting symbols of social memory. Memorial actions can be: in nature - peaceful or conflict; in purpose - aimed at preserving the existing model of national memory, its full or partial renewal or condemnation of alternative models; by emotional fullness - triumphantly sublime, mournful, neutral; in scale - international, state, regional, local.

According to the systematic approach in the study, it is necessary to characterise the structural, functional and normative aspects of the phenomenon of memory politics (Buley et al., 2018). Thus, the structural component makes it possible to characterise the key features and constituent elements of memory politics. The structural elements of memory politics include the following categories: character, specificity, functions, subjects of implementation and objects of direction, goals, objectives, forms of implementation of a specific policy. The specificity of memory politics is determined by the totality of its characteristic features and peculiarities. Its characteristic features are its immanence in the political system, inclusion in the humanitarian strategy of the state and focus on the actual needs and values of society. A feature of this policy is its instrumental character, which characterises it not as an independent sphere, but as complementary and interacting with other branches of government. For example, the actualisation of heroic and tragic images of the past, the formation of holistic stable pictures of the history of their people, the formation of a sense of patriotism and national self-awareness/identity are some of the fundamental 
tasks of the social, educational, cultural sectors of public administration. It can also be both an element of political management (systemic management of socio-political processes), and an integral part of political marketing (the introduction into practice of certain attitudes of collective consciousness in order to gain and retain control over the power market). Depending on the tasks set, the memorial policy is selective in relation to the memories that are actualised, and can also have a creative or destructive influence (Zhumasheva et al., 2014).

In general, the nature of memorial practices is quite multifaceted, so they can be interpreted in different forms:

- political manipulation of the past - according to implementation mechanisms;

- linguistic substantiation of the "effect of the reality of the past" - according to the way of expression and mythology;

- justification of the phenomenon of "memory drift";

- the topology of rancour - according to performativity;

- justified oblivion - according to the ethical relation to the past;

- simulation of reality - repetition, the formation of imaginary copies of what did not exist in reality;

- social drama - according to external manifestations and mechanisms of memory transfer;

- symbolic violence - in fact, as a manifestation of imperious compulsion;

- formatting of mass consciousness - as a way of constructing the content of collective memories, that is, their structuring in accordance with their significance;

- irrational stimulation based on retrospective practice, and not on prospective expediency - as a way of motivation;

- mass communication - according to the form of information transfer;

- social and political regulation aimed at managing the behaviour of a person and a group - according to a political goal.

According to temporal criteria, three groups of functions of memory politics should be distinguished, which can be conventionally called: "functions for the past", "functions for the present", "functions for the future". Functions "for the past" - preservation, reproduction and commemoration of the memory of social events, symbols, figures: functions of memorialisation, actualisation, consensus, glorification and victimisation. Functions "for the present" - the use of memory as: a) a criterion for assessing specific events; b) a template (matrix, diagram, mental map) for the social orientation of a person; c) a sample of desirable/undesirable behaviour; d) an incentive for repeating it or abstaining from it in a specific today's situation (functions of identification, didactic, compensatory, motivational, orienting, regulation, stabilisation, unification). This can turn into speculation on social topics for the sake of realising actual personal or corporate political interests (distracting, legitimising, destabilising, compromising functions). In the latter case, one speaks of a manipulative memory politics. Functions "for the future" - defining the prospects, vectors and strategies for the future development of the state, mobilising society for the implementation of these strategies: integration, motivational, mobilising, orienting functions.

These groups of functions are consonant, but not identical to the modes of historicity passéism, presentism and futurism. Ideally, these three groups of functions (other than manipulative ones) should be combined. As a result of this combination, memory politics should become an organic component of chronopolitics as a process of constructing political relations through the prism of the past for the sake of future political development. That is, these functions must be considered as a triune task - the formation in the public consciousness of the image of 
what it was, what it is and what the life of an ethnic group, society, nation, state will be, reconstruction and construction of this image in reality.

Among the subjects implementing memory politics, it is advisable to distinguish between institutionalised and non-institutionalised (Abisheva et al., 2019). Non-institutionalised subjects of memory politics carry out situational activities in this area. These include social movements and individual public figures. A detailed list of institutionalised subjects of memory politics by the specifics of their activities and differentiated into governmental and non-governmental. Government institutions that are subjects of the formation of public memory include: the Ministry of Education and Science; Ministry of Culture; official (government) press. Several groups are distinguished among non-governmental (non-governmental) institutions and public organisations:

1. Organisations created by direct participants in the events, eyewitnesses, victims. They are mainly carriers of tragic memory, respectively, their goal is to preserve and perpetuate the memory of "trauma". These organisations include: unions of former concentration camp prisoners and repressed; organisations of victims and participants in hostilities; social formations of ethnic minorities, which at one time were subjected to forced deportation and expulsion from their native lands; organisations of the indifferent to the consequences of environmental disasters of the past.

2. Public associations advocating the preservation and restoration of traditions, which can be classified as carriers of heroic memory. Their purpose is to preserve, return, restore former customs, traditions, way of life, norms and models of behaviour, and the like: military organisations (military formations, orders of knights, etc.); organisations of a socio-political nature (communist, monarchist, anarchist, etc.); elite organisations (noble associations); organisations of a religious and ethical nature.

3. Scientific, cultural and educational organisations, the purpose of which is to study and popularise knowledge about the past: research organisations; cultural and educational associations; societies whose activities are aimed at preserving and restoring historical and cultural monuments.

There is also a variant of classifying public organisations according to the priority of memory politics along with other activities: they specialise in memorial work (or it is the main one for them); are engaged in this type of activity along with other projects; from time to time participate in the implementation of the tasks of memory politics.

The object of the implementation of memory politics is society as a whole or its individual groups (social, ethnic, territorial, linguistic, etc.). At the same time, it is necessary to highlight the targets, the transformation of which the memorial policy is aimed at: public opinion, patriotic feelings, public will, social memory, national consciousness and identity. The purpose of such practices is to form and consolidate in society a model of memory and management of collective social consciousness for the implementation of the tasks of the political system. With the help of this policy, various interests can be implemented: harmonic and antagonistic, progressive, conservative and reactionary, permanent and temporary, stable and unstable, general and particular.

Derived from goals and interests are the tasks of these practices, which can be implemented as components of political management aimed at social (general) priorities, or political marketing, the purpose of which is to conquer power (private interests). The first group includes the following tasks: the formation of national identity; unification of different models of memory, reduction to the consistency of its official and unofficial levels; overcoming conflicting interpretations in the interpretation of the past; joining the efforts of members of a particular community, defending and strengthening their social positions; consolidation of society/nation, creation of unifying symbols; 
actualisation of socially significant past experience; demonstration of positive role models; mobilising the population to implement social transformations; support for domestic political stability; engaging an individual in the social experience of the community. The second group includes tasks that directly or indirectly related to memory politics: gaining, retaining or redistributing power; integration/disintegration of society; legalisation of political actions; compromising an ideological rival; demonstration of the continuity/consistency of social and political development (during campaigning); the formation of values and attitudes within the political sphere.

The forms of social policy implementation on the example of the activities of public organisations are differentiated into the following:

- collection, fixation, systematisation, storage and publication of documents, letters, memoirs, biographical, social and ethnographic materials;

- search, preservation and return to the scientific and cultural circulation of archaeological finds, social and cultural monuments, works of art, antiques and folklife;

- holding public and political actions (rallies, demonstrations, meetings, days of remembrance, etc.) in order to draw attention to the problems of preserving the historical and cultural heritage, language and traditions, dedicated to certain social dates, outstanding artists, public and political figures;

- the organisation of scientific and cultural and artistic events - conferences, symposia, forums, concerts, festivals, exhibitions, competitions, etc.;

- information and educational work (especially among young people): studying the native language, folk traditions, popularising folklore, disseminating social knowledge (including through the involvement of public agents - bloggers and the like);

- local history work, development of local tourism, creation of folk, ethnographic museums, etc.;

- preservation, development and popularisation of the culture, language and traditions of national minorities;

- development of interregional, interethnic and international cultural ties.

After the disclosure of the structural elements, it is worth proceeding to consider the functional components of the memorial policy, revealing the methods and means of its implementation. These include: the resources used in these practices, the intensity and sequence of deployment, procedures, mechanisms and stages of their implementation.

As is known, E. Toffler divided the resources of power into three groups: strength, wealth and knowledge. Similarly, this division should be considered three groups of resources of memory politics: power, economic, information. The power (coercive) resources of memory politics include: the legal framework (including memorial laws), lustration structures, the control and implementation system. They are used to standardise, organise and implement appropriate practices. Economic resources provide funding for memorial projects: the creation of new and streamlining of existing places of memory, holding ceremonies, publishing and distributing educational materials, implementing social media projects, and the like. The implementation of memorial practices is impossible without sufficient information support. Information resources include: expert/scientific knowledge, empirical and analytical results of monitoring studies, a system for forecasting, planning and developing programs for the implementation of social policy.

In terms of the content and intensity of the impact on public consciousness, it is possible to reveal the successive steps of introducing memory politics: 
1. Actualisation of existing public images of the past.

2. Correction of collective memory models without fundamental changes.

3. Qualitative transformation of old or introduction of new memory models.

4. Formation of new identities, evaluative systems, ways of behaviour (habits, traditions).

5. The use of fixed identities, attitudes, patterns of behaviour for the realisation of general social, corporate or private interests in the course of political activity.

For the first three steps, the past is the object of control and the goal of political influence (the formation of memories and assessments), and in the next steps, memory acts as a means of influence (the use of fixed images).

The mechanisms for implementing the state memorial policy are as follows:

- the adoption of laws and decrees regulating the nature, features of ceremonies and forms of honouring significant social events, figures, images (regulatory framework);

- development of educational programs and textbooks, taking into account the peculiarities of the formation of national memory (education);

- preservation of existing, creation of new memorial objects (places of memory) and their use to actualise images of the past (cultural landscape of memory);

- the formation of a pantheon of social heroes/martyrs (faces);

- introduction of a calendar of social holidays (events);

- implementation of appropriate collective traditions/rituals of celebration (behaviour);

- focusing on the authority, uniqueness, reliability, usefulness of information about the past, sources of origin and means of transmission, as well as actions that are stimulated by this information (relevance).

Often focus is on the existence of two levels of collective memory: the official, which is purposefully constructed and regulated by the authorities, and the unofficial, which is formed by spontaneous social processes. Therefore, as indicated above, overcoming the contradictions between these levels is one of the key tasks of the state memory politics. The following stages of its implementation can be suggested:

1. Articulation of political interests.

2. Formulation of the official level of collective memory (creation of a basic narrative) corresponding to the interests of social and political development - the development of ideal models (normative analysis).

3. Monitoring the initial state of the unofficial level of social memory (existing state of mass consciousness) - analysis of the existing state of social memory (positive analysis).

4. Search for effective mechanisms for managing social consciousness (consolidation/approximation of the informal and official levels of memory).

5. "Piloting" - testing the proposed mechanisms on the example of a limited target audience in order to obtain practical conclusions regarding possible dissemination at the level of the whole society.

6. Implementation of memory mechanisms at the mass level.

7. Monitoring the final state of public social consciousness. 
8. Evaluation of the achieved results in accordance with primary interests and the formation of new goals.

Like any system, memory politics is based on normative principles that determine the schemes, models and principles in accordance with which these practices are implemented. Regulatory aspects include: principles of implementation, types, models, tactics and strategies for the implementation of memorial policy. Memory politics should be implemented in accordance with the principles of: compliance with the tasks of social development; the consistency of strategies for implementation by various actors in the political process; taking into account the states of collective consciousness, the unofficial level of memory; consistency of the realities of social development with the achievements of social science; lack of imperative and violence; accounting for cognitive features and memory processes. Moreover, historians determine the need to form a state memorial policy based on the principles of equality and counteraction to all forms of discrimination of memory models, regardless of ethnic, political, ideological, religious source of their emergence in conditions of polyethnicity and polyconfessionalism. Of course, in the conditions of stagnation of state development, memory models that are used in various kinds of propaganda and pose a threat to state interests are taken out of the brackets in such a liberal approach to the formation of an inclusive national memory.

Social memory can be a significant conflict-generating factor, retaining memories of past social interethnic grievances, disputes, enmity. Thus, the coexistence of different interpretations of the past, contradictory with each other, leads to states that are defined as "wars of memory" or "conflicts of memory", which from the symbolic plane can turn into real civil confrontations or provoke and exacerbate international conflicts. Therefore, one of the main tasks of memory politics is to promote their prevention and resolution. Analysing world experience, there are several options for resolving such conflicts, which in fact constitute various types of implementations of memorial policy:

- aggressive memory politics - forcible imposition of the dominant version of the perception of the past, as in interwar Poland and Romania. A risky and dubious method that requires significant centralisation of power and sufficient resources to implement. The danger also lies in the fact that this method can lead to the opposite consequences - the actualisation of alternative assessments of the past;

- nihilistic approach - ignoring conflicts of memory, relying on natural oblivion. But each generation, social or ethnic community naturally strives to have its own history and preserve its memory, despite the fact that the uniqueness of this community is ignored by the official authorities;

- the politics of ridicule - parting with laughter with one's own past (example of Great Britain, where television shows which openly mock English traditions are common). However, jokes with their own history can be perceived as a national grievance;

- the oblivion pact- the elimination of conflicting and unpleasant stories from the public discourse. Examples are Konrad Adenauer's Germany and Spain after Franco's regime. However, such a pact has a limited duration. Over time, disputes about the past flare up even more intensely;

- public indifference to the past is a consequence of pride in the present. An example is modern Spain, in which the population does not have a noticeable interest in their own history, but they are proud of the current successes of the country and are interested in future achievements.

Possible types of memory politics are considered somewhat differently according to the criterion of the level of culture of power and social tolerance: 
- indifferent - the establishment of such rules of political cohabitation, under which state institutions, political forces and the public are mostly indifferent to various views on the past and the adoption of different practices; the latter seem unimportant against the background of basic socio-economic problems;

- confrontational - limiting the manifestations of tolerance, the perception of another version of the past as alien and incomprehensible, the carriers of which cannot be brought into cooperation;

- condescending - the dominance of one of the narratives, in which others are assessed as weaker, the existence of which can be simultaneously admitted and despised;

- critical polylogical - respect for the opinions, values, traditions of the other, the ability to change the adopted narratives in the process of constructive social discussions, with the emergence of new evidence, renewal of research opportunities.

Summarising the above approaches, three possible variants of the official memory politics as memorial reconciliation can be distinguished:

1. forcible elimination, but not the solution of a conflict of memories through the imposition of a dominant position (aggressive or confrontational type of memory politics);

2. ignoring, belittling existing contradictions in the interests of implementing programs of socio-economic development (an indifferent, nihilistic type of memory politics, a pact of oblivion, public indifference to the past);

3. initiation of a dialogue on controversial issues, which may result in "overcoming the past", symbolic repentance and forgiveness of offences (condescending and critical-polylogical types).

This concerns the consideration of models of reconciliation politics regarding memory conflicts. In general, the implementation of the memorial policy is systematically revealed through the appropriate models, tactics and strategies. Using a systems approach, memory politics model should be defined as a combination of three components: functional, structural and normative. The functional component determines the nature of the respective memorial practices, in particular: the form and content of politics, methods of preservation, reproduction and memory, means of "overcoming" the past and consolidating a common identity. Structural - contains a list of key events, symbols, narratives. Normative - includes evaluative characteristics and methods of attitude to conversion problematic social phenomena. Appropriate visions of memory politics models are used to compare memorial practices. The tactics of memory politics is a sequence of immediate short-term tasks, priorities, interests, formed and embodied under the influence of external conditions. Tactics are a tool for implementing strategy. Memory politics strategy is a long-term, consistent, constructive, rational program that is based on ideological priorities and monitoring indicators and determines the direction of memory politics towards achieving its overall goal. In general, the model determines what is preserved in the public consciousness, how it is evaluated and in what ways the saved is actualised. And the strategy and tactics formulate in accordance with the distant and near perspective, the vector of the deployment of the memorial policy and the connection with other sectors of political administration, a general guideline and individual steps leading to its implementation.

\section{Conclusions}

The state potential of memory politics is unconditional. Thus, the implementation of memory politics on the basis of various principles can lead to the formation of various types of statehood. The most striking example in this context is the comparison of the national and Soviet models of 
memory in post-Soviet countries. The study of the process of institutionalisation of social memory is facilitated by the definition and analysis of the functions of social memory. In this regard, it is possible to talk about a combination of institutional and functional approaches to the study of the current state of social memory.

In the process of interpreting the messages of the past, one can also rely on the methodological provisions of hermeneutics, psychosocial-semantics, social and cultural anthropology, visual sociology. There are tangible and intangible carriers of social-historical memory. Based on this, one should involve the argumentation of the sociology of things, which suggests considering the material components of social interaction. Things act as actors of social interaction, influencing relations between people, interfering with the configuration of social forces. Thus, national symbols, being material carriers of social-historical memory, act as a symbolic accompaniment to political manifestations, being included in the processes of society segmentation. Social memory at the personal level, as a component of the individual's memory, is included in the habit of the face. In this regard, Bourdieu's theory of the structure and properties of habitus can help to reveal the characteristics of social memory. Memory can be viewed as a mechanism for the formation of habit. Proceeding from the fact that the habit is not recognised and not reflected by the person, it can be argued that the social memory of a person affects his social behaviour without clear reflections and passes the mechanism of self-control. This makes it difficult to study social memory, prompting the use of indirect methods for analysing habit and its components. Thus, the problem of social memory covers a significant range of aspects of research interest and requires a poly-paradigmatic approach for its study.

\section{References}

Abisheva, K.M., Nagimzhanova, K.M., Aykenova, R.A., Kapanova, A.K., Koldasbayeve, Z.S., and Kanapyanova, A.D. (2019). Cross-cultural competence of communicators as a way to create a positive eco-informational environment. Space and Culture, India, 7(2), 76-88.

Bekus, N. (2019). Agency of internal transnationalism in social memory. British Journal of Sociology, 70(4), 1602-1623.

Bocharova, O.A. (2018). From multicultural society to intercultural education. Bulletin of Mukachevo State University. Series "Pedagogy and Psychology", 2(8), 17-21.

Buley, N.V., Melnichuk, A.V., Demchenko, M.V., Chizhankova, I.V., Makushkin, S.A., Ilina, I.Y., and Bondaletova, N.F. (2018). Improving corporate youth programs of companies with significant shares of public capital. Modern Journal of Language Teaching Methods, 8(10), 509-518.

Carleton, W.C., Conolly, J., and Collard, M. (2013). Corporate kin-groups, social memory, and "history houses"? A quantitative test of recent reconstructions of social organization and building function at çatalhöyük during the PPNB. Journal of Archaeological Science, 40(4), 1816-1822.

Delyser, D. (2015). Collecting, kitsch and the intimate geographies of social memory: A story of archival autoethnography. Transactions of the Institute of British Geographers, 40(2), $209-222$.

Foster, W.M., Suddaby, R., Minkus, A., and Wiebe, E. (2011). History as social memory assets: The example of tim hortons. Management and Organizational History, 6(1), 101-120.

Gainullina, F.A., Muhazhanova, R.M., Kabyshev, T.B., and Baigabylov, N.O. (2014). M.O. Auezov's contribution to the historical and cultural landscape of the Semipalatinsk Cisirtysh Area: Revisiting the issues of the modern local literary history. Asia Life Science Journal, 11(6 SI), 512-517. 
Henninger, M., and Scifleet, P. (2016). How are the new documents of social networks shaping our cultural memory? Journal of Documentation, 72(2), 277-298.

Hewer, C.J., and Roberts, R. (2012). History, culture and cognition: Towards a dynamic model of social memory. Culture and Psychology, 18(2), 167-183.

Kukharchuk, O.S. (2018). Cultural connections of the Transcarpathian people with the population of Ukrainian regions: literacy, birth of historic knowledge, education. Bulletin of Mukachevo State University. Series “Pedagogy and Psychology", 1(7), 29-33.

Lalioti, V. (2002). Social memory and ethnic identity: Ancient Greek drama performances as commemorative ceremonies. History and Anthropology, 13(2), 113-137.

Maswood, R., and Rajaram, S. (2019). Social Transmission of False Memory in Small Groups and Large Networks. Topics in Cognitive Science, 11(4), 687-709.

Mistry, J., Berardi, A., Haynes, L., Davis, D., Xavier, R., and Andries, J. (2014). The role of social memory in natural resource management: Insights from participatory video. Transactions of the Institute of British Geographers, 39(1), 115-127.

Olick, J.K. (2009). Between chaos and diversity: Is social memory studies a field? International Journal of Politics, Culture and Society, 22(2), 249-252.

Olick, J.K., and Robbins, J. (1998). Social memory studies: From "Collective Memory" to the Historical Sociology of Mnemonic Practices. Annual Review of Sociology, 24, 105-140.

Overholtzer, L., and Bolnick, D.A. (2017). The Archaeology of Commoner Social Memories and Legitimizing Histories. Journal of Archaeological Method and Theory, 24(1), 50-89.

Poghosyan, V. (2018). Philosophies of social behavior research: Meta-analytic review. Wisdom, 11(2), 85-92.

Romano, M., Tran, E., and Moscovitch, D.A. (2020). Social anxiety is associated with impaired memory for imagined social events with positive outcomes. Cognition and Emotion, 34(4), 700-712.

Sebald, G., and Weyand, J. (2011). Zur Formierung sozialer Gedächtnisse. Zeitschrift Fur Soziologie, 4o(3), 174-189.

Skrypnikova, V.O. (2020). The concept of intercultural competence: essence and content. Scientific Bulletin of Mukachevo State University. Series "Pedagogy and Psychology", 1(11), 210-216.

Swann, W.B., and Miller, L.C. (1982). Why never forgetting a face matters: Visual imagery and social memory. Journal of Personality and Social Psychology, 43(3), 475-480.

Tileagă, C. (2012). Communism and the Meaning of Social Memory: Towards a Critical-Interpretive Approach. Integrative Psychological and Behavioral Science, 46(4), 475-492.

Tovkanets, H.V. (2020). Research activity in the development of creative potential of the modern specialist in the conditions of socialization. Scientific Bulletin of Mukachevo State University. Series "Economy", 1(13), 118-122.

Williams, R. (2011). BTB readers' guide: Social memory. Biblical Theology Bulletin, 41(4), 189-20o.

Wilson, G.A. (2015). Community resilience and social memory. Environmental Values, 24(2), 227-257.

Wilson, G.A., Kelly, C.L., Briassoulis, H., Ferrara, A., Quaranta, G., Salvia, R., and Zhang, P. (2017). Social Memory and the Resilience of Communities Affected by Land Degradation. Land Degradation and Development, 28(2), 383-400.

Zhumasheva, A.S., Sametova, F.T., Muktarova, E., Batyrkhan, B.S., and Sultaniyazova, I.S. (2014). About a lingvocultural interference in the conditions of dialogue between cultures. Life Science Journal, 11(SPEC. ISSUE 7), 360-364. 